\title{
The Subaltern Voice in Kylas Chunder Dutt's A Journal of Forty-Eight Hours of the Year 1945
}

\author{
Paromita Sengupta \\ Sovarani Memorial College, Jagatballavpur, Howrah. ORCID: oooo-ooo2-3381-0726. \\ Email: paromitaseng@gmail.com
}

Received May 15, 2017; Revised July 03, 2017; Accepted July 15, 2017; Published August 11, 2017.

\begin{abstract}
This paper reads Kylas Chunder Dutt's short fictional text A Journal of Forty-Eight Hours of the Year 1945 (1835) as a postcolonial voice, engaged in the act of representation, and of interrogating colonialism much before postcolonialism took formal shape as a theoretical practice. The text represents the injustice of subaltern oppression, and, what is more crucial, more vital, prophetically uses the word "subaltern" in its present post-modern signification. Dutt's writing enclosed within it the inescapable multi-tensions of the Bengal-British cultural negotiation, of which it was the product, but it was simultaneously implicated in the process of indigenous identity formation and in the formulation of subaltern consciousness. The text not only suggests armed conflict as a tool of opposing colonialism, it is also prophetic in its use of the concept of the subaltern as far back as 1835- about a hundred and fifty years before Subaltern Studies was formally born.
\end{abstract}

Keywords: Identity, India, Nationalism, Subaltern

\section{Introduction}

Customarily, the narrative of Indian Writing in English is perceived to have been inaugurated in the 1930s. This idea has been built on the erasure of the Nineteenth Century lineage of Indian Writing in English which has been given little literary, historical or even archival value. While the poetry written in English by Indians in the Nineteenth Century has received some critical attention, fiction and drama have been dismissingly treated as "crude", "exotic", and "rootless". The latter has found place solely in literary histories which commonly trace the "true" beginnings of Indian Writing in English to the trio of R.K. Narayan, Raja Rao, and Mulk Raj Anand (all of whose works were first published in the 1930s). Some of the few studies in this area are Gobinda Prasad Sarma's Nationalism in Anglo-Indian Fiction (1978), Subhendu Mund's articles on Kylas Dutt and Shoshee Dutt and those by Alex Tickell. Recently Kalyan Dutt and Somdatta Mondal have brought out editions of Kylas Dutt's works (See References for details). Our postcolonial sensibility certainly asks us to re-consider/re- view the coloniser-colonised negotiations in far greater detail and with more attention than it has so far received.

The therapeutic retrieval of the beginning of Indian Writing in English is absolutely necessary today because the forgotten archive of the colonial encounter narrates manifold chronicles of contestation- "the colonial archive preserves those versions of knowledge and agency that were produced in response to the particular pressures of the colonial encounter" (Gandhi p. 5). The initial group of authors writing in English in Nineteenth Century Bengal

(C) AesthetixMS 2016. This Open Access article is published under a Creative Commons Attribution Non-Commercial 4.0 International License (http://creativecommons.org/licenses/by-nc/4.0/), which permits non-commercial re-use, distribution, and reproduction in any medium, provided the original work is properly cited. For citation use the DOI. For commercial re-use, please contact editor@rupkatha.com. 
countered the mainstream version of history and anticipated the stance of the Subaltern Studies Group (the influential school of Indian historiography founded by Ranajit Guha in the early 1980s) which drew attention to "the small voice of history". In his powerful essay "Chandra's Death", Guha restates the Subalternist position thus:

The ordinary apparatus of historiography has little to offer... Designed for big events and institutions, it is most at ease when made to operate on those larger phenomena which visibly stick out of the debris of the past. As a result, historical scholarship has developed... a tradition that tends to ignore the small drama and fine detail of social existence, especially at its lower depths (p. 138).

Questions which have been central to the subaltern studies are: Can history be written outside the dominant structures of history (such as colonialism)? Who has the authority to interpret historical events and how does the writer's consciousness influence his writing of history? What are the documents that are ordinarily overlooked in history writing? How are documents and archives interpreted? How far and in what way can socio-historical documents be reclaimed? And, most importantly what constitutes history and to what ends and purposes history is written? It is the quest for an answer to these very questions that led to the study of English texts written in Nineteenth Century Bengal. India's colonial past was the scene of intense discursive and conceptual activity, characterized by a profusion of thought and writing about the cultural and political identities of the Indians by the Indians themselves, both in the indigenous languages as well as in English. These texts function as socio-historical documents that attempted to chronicle contemporary life outside the dominant structure of colonialism. Since these texts were relegated to the background first due to colonial convenience and later due to habitual negligence it has become absolutely necessary that we retrieve them from anonymity and critical neglect.

This paper looks at one such text - a fictional prose narrative written by Kylas Chunder Dutt- A Journal of Forty-Eight Hours of the Year 1945 (published in Calcutta Literary Gazette, 6 June, 1835). Kylas Dutt - a product of the Bengal-British colonial encounter, and the resulting cultural interface, particularly colonial education- belongs to the class of indigenous bourgeoisie who have been mostly read as "spawned and nurtured by colonialism itself...Pliant and prone to compromise" (Guha 5). This paper reads Dutt as a postcolonial voice, engaged in the act of selfrepresentation, and of interrogating colonialism much before postcolonialism took shape as a theoretical practice. ii One shall see how his writing enclosed within it the inescapable multitensions of the cultural negotiation, of which it was the product, and how it was simultaneously implicated in the process of indigenous identity formation and in the formulation of desh-bodh. ${ }^{\text {iii }}$ Dutt's text not only suggests armed conflict as a tool of opposing colonialism, it is also prophetic in its use of the concept of the subaltern.

\section{English in Nineteenth Century Bengal}

The use, abuse and the relevance of English in the (post)colonial societies has always been a widely discussed and debated matter. Postcolonial studies consistently stress that one of the main characteristics of colonial domination is control over language, which becomes the medium through which "a hierarchical structure of power is perpetuated, and the medium through which conceptions of 'truth', 'order', and 'reality' become established" (Ashcroft et al, 7). Thus postcolonial studies emphasize that in the colonised countries, English literature was "invented" as a hegemonic discourse to create, sustain and communicate the myth of British cultural 
hegemony. Following the argument in Said's Orientalism (1978), which posited that the West had not only dominated the East politically but also that Western scholars "wrote" Asia's past and constructed its modern identities from a perspective that takes Europe as the norm, from which the "exotic", "inscrutable" Orient deviates. Gauri Viswanathan, in her book Masks of Conquest, alleges that in the colonial period the literary text functioned as a mirror of the ideal Englishman and thereby became a mask of exploitation that masked/disguised the material activities of the colonizing British government. Viswanathan here draws upon Antonio Gramsci's theory on the associations of culture and power, that cultural domination works by consent and can (and often does) precede conquest by force. Gramsci posits that intellectual and physical power operate parallel to each other:

...the supremacy of a social group manifests itself in two ways, as "domination" and as "intellectual and moral leadership". ... It seems clear . . . that there can and indeed must be hegemonic activity even before the rise to power, and that one should not count only on the material force which power gives in order to exercise an effective leadership (p. 57).

This paper contends that while it is true that Western cultural colonization operated parallel to the political and military conquest of its colonies, in India this cultural colonization was not uncontested, and that the results of this cultural imposition were not always in cue with the coloniser's intent or expectations. India fought back at all levels- not just military and political but also cultural. Unlike the "native intellectuals" of Fanon (Black Skin White Masks), very strong voices, voices that we may today label as postcolonial, are to be found in the writings by Indians in the nineteenth century, both in the vernacular languages as well as in the acquired language of the colonisers, English. However, unlike the classic postcolonial example of Shakespeare's Caliban-the colonised Indian/Bengali did not learn the coloniser's language just to go on to curse his master. The response was much more complex and layered, subtle and sustained.

The Nineteenth Century Western educated colonised Indian/ Bengali's response/strategy from the very beginning was to use the new language for his own purposes-to participate in the ongoing discourses and to produce a vast body of discursive, polemical and literary texts. Rammohan Roy (1772-1833) is the one of the first, but by no means the sole representative, of this group of, to use Fanon's terminology, "native intellectuals". The positive reception of certain Western ideas, and the fact that the early Indian writers were influenced by their Western counterparts and wrote in English (as opposed to indigenous languages) should not be immediately read as "cultural colonization". The use of the English language by these authors is subversive, because the English language was often being used to articulate indigenous identities, to challenge the grand narratives of history, power, politics, identity and social consciousness.

Early Nineteenth Century Bengal was at the cross-currents of three important phenomena- the establishment of the Hindu College on January 20, 1817 which represents the first collective effort made by Indians themselves for the education of their children in English language and literature, the transmission of new cultural attitudes through British Orientalism, and the Charter Act of 1813 which paved the way for the Christian Evangelicals who validated the imperial process through the concept of the civilizing mission. While many conversions (Krishna Mohan Banerjee, Michael Madhusudan Dutt, and Lal Behari Day) attested their success, these missionaries also created a powerful impetus to reformulate and understand the Hindu traditions in the light of modernity. The educated Bengali elite became keen on religious reform and attempted to redefine and defend Hindu ideas in modern (contemporary) terms.

Bengal's interface with the British culture and literature thus led to complex cultural relations and negotiation of ideas that were developing and mutually shaping each other 
throughout the nineteenth century. A new social, intellectual and political milieu was taking form in the wake of the interface of the two hitherto alien cultures, the primary site of which was the Hindu College. The college created a class of bourgeoisie that attempted to recover "the very tradition that, at other times, it seemed intent on redefining or even disowning" (Amit Chaudhuri p. 3). Partha Chatterjee speaks of the "eastern" type of nationalism as being characterised by "an effort to're-equip' the nation culturally, to transform it." Chatterjee says that this could not be done by simply "imitating the alien culture", because then the nation would lose its "distinctive identity": "The search therefore was for a regeneration of the national culture, adapted to the requirements of progress, but retaining at the same time its distinctiveness" (Chatterjee p. 2). Postcolonial theorists like Leela Gandhi have dealt with this problematic "ambivalent and symbiotic relationship between coloniser and colonised" (Gandhi p. 11). The colonial annals of Bengal alleviate any attempt to homogenize the relationship between the coloniser and the colonised into a simple dichotomy of oppressor and oppressed. In such context, the literature written in English in the changing social, cultural, religious and economic climate of Nineteenth Century (post)colonial Bengal may be seen as diverse, complex, indigenous responses to the surfacing of two seemingly paradoxical intellectual phenomena: the radical nationalism that univocally repudiated the idea of the empire, and the cultural pluralism that made the idea of progress rationally acceptable.

\section{A Journal of Forty-Eight Hours of the Year 1945}

Kylas Chunder Dutt (1817-1857), whose text A Journal of Forty-Eight Hours of the Year 1945 (henceforth referred to as Forty-Eight Hours) is the focus of this paper, belongs to the family of the Rambagan Dutt's who were descendants of Nilmoni Dutt, who had settled in Calcutta from his ancestral home in Burdwan in the eighteenth century. Once he settled in Calcutta, Nilmoni rapidly established himself as a leading citizen. His eldest son, Rasomoy (1779-1854), was a judge of the Small Cause Court in Calcutta and secretary of the management committees of both the Hindu College and the Sanskrit College. Rasomoy's eldest son was Kishen Chunder, Kylas Chunder, Govin Chunder (1828-1884), Hur Chunder (1831-1901) and Greece Chunder (1833-1892), were anglophone poets. Kylas was his Rasomoy's second son, and was the first Indian to publish fiction in English (A Journal of Forty-Eight Hours of the Year 1945, published in 1835). Nilmoni's youngest son was Pitamber, whose sons were Ishan Chunder (Romesh Chunder's father) and Shoshee Chunder. Kylas and Shoshee were thus first cousins. Somdatta Mandal makes the following interesting comment about Kylas Dutt in her edited book:

1817, the year of his birth, was also the year in which Hindoo/Hindu College was established in Calcutta. 1835, the year in which he wrote A Journal of Forty-Eight Hours of the Year 1945 and edited the first two issues of the Hindu Pioneer was also the year in which T. B. Macaulay wrote his Minutes of Education, ... The year 1857 in which Kylas died an untimely death was... the year of .. the first major attempt by Indians to liberate their motherland from imperial rule. (p. 9)

There is an interesting story regarding the sudden conversion to Christianity of one branch of the family. When Kishen Chunder, the eldest son of Rasomoy Dutt, fell mortally ill, immediately after their father's death in 1862, he is said to have seen a vision of the next world on his deathbed and asked to be baptised. In "Introducing South-Asian Poetry in English: The Dutts of Rambagan", Kaiser Haq recounts, “The cleric sent for evaded the request--lest, one assumes, Hindus accused him of stealing a dying man's soul. The youngest brother Greece, who himself was unbaptized, then administered the baptismal rites. The dying Kishen adjured his brothers to embrace 
Christianity, which they presently did, en famille." Pitambur's side of the Dutt family remained Hindu. Haq further notes that, though the relationship between the Christian and the Hindu sides of the family remained genial, "...the conversion did result in a slight difference in outlook, which noticeably affected their literary productions". The "unconverted Dutts" were set apart from their Christianised kin in their nationalist outlook. The term "nation" (and its allied terms such as "nationalist", "nationality") has acquired a lot of political and theoretical baggage in the last few decades after the Second World War, but we find the term "nation" used by Shoshee Dutt as early as 1845 in his fictional work Republic of Orissa Annals from the Pages of the Twentieth Century. Haq cites the "political difference" between the Christian and the Hindu Dutts by illustrating two sonnets with the same title, "India": Both evince the self-conscious Indianness fostered by the Bengal Renaissance, but with different accents. The poem by the Christian Hur Chunder, after declaring "boundless love" to the "Land of my birth" mourns her lost glory and looks towards the future: "But Time shall yet be mocked:--though these decay,/I see broad streaks of a still brighter day." There can be no doubt that the Hur Chunder's "brighter day" is materialising under the aegis of British colonial rule. Shoshee Chunder's "India", on the other hand, is an exhortation to seek independence:

I dreamt a dream of strange and wild delight, Freedom's pure shrine once more illumed did seem,

Science again aspired to the sky,

And patriot valour watch'd the smiling strand:

A dream! A dream! Why should a dream it be?

Land of my fathers! Canst thou never be free?

(S. C. Dutt, "India")

There is confusion among scholars about the issue of conversion: In "The Dutt Family Album: And Toru Dutt" Rosinka Chaudhuri writes, "Rasomoy's sons, along with their cousin Shoshee Chunder Dutt (1824-86) converted to Christianity after the death of their father." (p. 55). Alex Tickell, referring Rosinka Chaudhuri, shares the same view in Terrorism, Insurgency and Indian English Literature, 1830 - 1947 (p. 6o). Somadatta Mandal, who has brought out an edition of Dutt's Journal in 2014, agrees with Haq that While Rasomoy's family embraced Christianity, "Pitamber's family mostly remained in the Hindu fold (p. 8). However, what should be more pertinent is that whether Shoshee converted to Christianity or not, his dream for his country is that of freedom. A similar feeling for the country and country-men is to be found in Revd. Lal Behari Day's Bengal Peasant Life (1878), a fictional narrative written much after Day's conversion. Haq's reading of "political difference" between Hindu and Christian Dutts, his mingling of religion with politics, certainly points out how biased we become with converts and conversion, how religious difference/conversion is often dangerously associated with patriotism or the lack of it.

The same dream that Shoshee has for a free India is what makes Kylas Dutt's fiction FortyEight Hours such an interesting text. At the time when Forty-Eight Hours (1835) was written the concept of nationalism was in its early stages in India/ Bengal. Kylas Dutt is one of the first of those intellectuals who were engaged in the task of imagining and consolidating the idea of nationalism. In 1835, Kylas Chunder Dutt, then an eighteen year old student of the Hindu College, wrote a prize winning prose fiction for his college competition about India of a hundred years later. The piece was titled "A Journal of Forty-Eight Hours of the Year 1945", and here the young Kylas revolutionarily fantasized that the students of the Hindu College have risen in armed rebellion (though unsuccessfully) against the British. The text was published in Calcutta Literary 
Gazette, or, Journal of Belles Lettres, Science, and the Arts, Vol. III, new series, no.75 (dated 6 June, 1835), a journal edited by D. L. Richardson, the well-known journalist, poet, and Principal of the Hindu College. What prompted Richardson to publish such a rebellious text is itself a matter of enquiry and can be a subject of research.

Looking for it more than 150 years after its publication, it was a mission almost impossible to trace this text. ${ }^{\text {iv }}$ After being "discovered" by Pallab Sengupta in 1965, who wrote about it in Bangla translation and commentary, "Sashastra Sangram, Swadhinatar Spriha, o Young Bengal" ["Armed Struggle, Zest for Freedom, and the Young Bengal],published in Chatuskone, a Bangla quarterly, in the Ashwin 1372 (probably 1965 in English calendar) issue. Amalendu Bose later wrote an article "Bengali Writing in English in the Nineteenth Century", which was published in the Bulletin of the Department of English of Calcutta University and which carried an analysis of Dutt's text. It was later included in bibliographies of Indian English fiction, and Govind Prasad Sarma discussed the text in Nationalism in Indo-Anglian Fiction (1978). The wide range of Sarma's study, beginning with fictions (both short stories and novels) published since 1835 and ending with those published after independence in 1947, restricted detailed discussions of individual works. Sarma also fails to emphasize that Indian authors writing in English had begun to propagate the idea of nationalism through their works before the Indian National Movement took concrete shape. He does not spell out how, from the earliest prose-fiction authored by Kylas Chunder Dutt, the idea of India as a nation was being proclaimed nor does he discuss Indian fiction in English against models of India as represented by typical British Anglo-Indian writers such as Kipling.

Portsmouth based scholar Alex Tickell, has an interesting story to tell about its rediscovery: having come all the way to Kolkata to search the text, he returned disappointed only to find it in "a second-hand book shop in Leeds." Tickell says

"The work of colonial acquisition had already been done for me by a Victorian missionary... Holding his copy of the Gazette I remembered the words of a Bengali academic I'd spoken to about the find, who said acerbically: "You should have known it was in the UK, after all, aren't all our treasures over there?" (Wasafiri, pp.10-14)

Tickell's experience illustrates the neglect of our archival materials, but, more importantly, it raises a very pertinent question about trans-cultural negotiation and heritage. For Tickell, Kylas Chunder Dutt marks the beginning of "a long, complex literary dialogue between cultures", the dialogue which is kept in motion by scholars like Tickell himself who took such pains to re-locate this "lost" text.

This text is not only the first work of prose fiction in Indian English literature, but also the first work of fiction of all modern Indian literatures that has an armed rebellion against the British as its theme. The story essays mistrust and revulsion against the British rule. This narrative is not only remarkable for its attitude to colonialism, but also for its negotiation with the English language and English education. It records the earliest fictional militant patriotic outburst in India and was written twenty years earlier than what is called the "First War of Indian Independence" or the "Revolt of 1857". However, Nineteenth Century India had already witnessed numerous peasant and tribal insurgencies. The first armed protests against British colonialism had come from "subaltern" quarters rather than from the Western-educated "civilised" members of the society. In Colonialism, Culture, and Resistance, K.N. Panikkar points out that though "early colonial historians and their disciples have drawn the picture of a docile and contented peasantry living under the shelter and comfort of Pax Britannica", it is but a "misleading picture", and Kathleen Gough has identified seventy seven peasant revolts in various parts of India, "the 
smallest of which probably engaged several thousand peasants in active support of combat". The $\mathrm{Kol}$ insurrection dates as far back as 1831 and in 1855 several thousand Santhals had rebelled.

In such context, it is worthwhile to examine Dutt's negotiation with Western culture and Western education, his early interrogation of colonialism, and the nascent stirrings of militant nationalism embedded in this valuable text. Since intellectuals like Kylas Dutt could not take up arms literally against the British, perhaps texts such as these were the sites where they could imagine rebellion and gratify their aspiration for liberty.

Though written in 1835, Kylas Dutt sets his story in the year 1945. By locating the events of the story a hundred years later than the date of its composition, Dutt underlines the strong wishfulfilment aspect of the theme. A militant uprising against the British was at that time a distant reality, something that could only be imagined to take place sometime in the future, not in the present. The choice of his date of imagined rebellion, 1945, may be arbitrary, yet it is thrillingly near to the actual date of Indian independence, 1947.

The text opens with the description of India's oppression under the tyrannical British rule:

The people of India and particularly those of the metropolis had been subject for the last fifty years to every species of sub-altern oppression. The dagger and the bowl were dealt out with a merciless hand, and neither age, sex nor condition could repress the rage of the British barbarians. These events, together with the recollection of the grievances suffered by their ancestors roused the dormant spirit of the generally considered timid Indian (Italics mine) (p. 15). ${ }^{\mathrm{v}}$

It is of great interest to note the avant-garde use of the word "subaltern" in the text, much before post-modern theorists coined its current signification. Taking the postcolonial signification of the term from Gramsci, Ranajit Guha formulated a new narrative of the history of India and South Asia in the 1980s. While Gayatri Chakravorty Spivak famously suggested that the subaltern is denied access to both mimetic and political forms of representation (Spivak, pp. 271-313), in the year 1835, Kylas Dutt in his Forty-Eight Hours had already endeavoured to represent the injustice of subaltern oppression, and, what is more crucial, more vital, had prophetically used the word "subaltern" in its present post-modern signification. The story shows how, unable to tolerate the cruelties of the British, a group of ex-students of the Anglo-Indian (Hindu) College decided to drive away the British from India. In this endeavour they are supported by "many of the most distinguished men of Calcutta—baboos, rajahs, nabobs".

Their leader Bhoobun Mohun (Bhoobun=world, Mohun=one of the names of Lord Krishna, who, according to Hindu belief is supposed to deliver the people from their persecutor) inspires them thus in one of their meetings: "This meeting is disrupted by the "red coats" which results in a skirmish, leaving many dead and wounded on both sides. Thus begins the rebellion. When the Governor hears about the incident, he writes a letter to Colonel Blood Thirsty (all the character names in the text are explicatory, like the names of the characters in the Morality Plays) stating that some natives are gearing up for an armed rebellion, in which circumstance all efforts should be made to secure Fort William against the natives. He sends a press note to the journal "The Calcutta Courier" alleging that a group of hooligans had been creating trouble in north-east Calcutta and when the soldiers tried to disperse them by firing blankly in the air, a few of the crowd jumped into the water and injured themselves. ${ }^{\mathrm{vii}}$

On the other hand, Bhoobun Mohun returns from the disrupted meeting worried and anxious. The mutineers meet in his house, and they decide to take possession of Fort William one day later. The next day, one of the leaders withdraws himself from the rebellion on the pretext of 
personal safety. Bhoobun Mohan and Ganga Narayan however remain determined about their goal of liberating their mother land. The next day "nothing was to be seen but turbaned heads, pikes, muskets and halbets reflecting in glittering colours the palm beams of the moon" (p. 18). The young leader Ganga Narayan is dragged into the fort when he challenges the British soldiers and asks them to surrender the fort to the Indians. Ganga Narayan is killed and his dead body is mockingly suspended in the air by the "civilized" British. A tough fight follows. Bhoobun Mohan injures the commander of the British army. Ultimately however, the Indians are defeated. Bhoobun Mohan and nine other rebel leaders are taken prisoners. In his article "Midnight's Ancestors" Alex Tickell notes that,

In the second edition of the Pioneer [a short-lived monthly journal devoted to literary matters that he edited with Bhuban Mohan Mittre], the eighteen-year-old Kylas had warned his companions at the college not to regard the journal as a political forum: "It may not be amiss if we venture to advise our young fellow students... to refrain from entering at present into the din of newspaper strife or of religious or political controversy, as such a procedure will bring the paper into disrepute and frustrate the end for which it has been established". In the same year, however Kylas had shown no such scruples in submitting his highly political short story... (p. 13)

Tickell further notes that,

It is difficult to account for this inconsistency in Kylas' views on politics and publication. Perhaps he thought that the stature of the Literary Gazette would protect him from possible reproach, or maybe he was just worried that his fledgling journal would lose its literary focus amidst the impassioned political debates... Whatever conclusion we come to about Kylas' wider literary-political aims, it is telling that the publication of his provocative "Journal of Forty-Eight Hours..." coincides with Charles Metcalfe's Press Act XI of 1835, in which the Governor General abolished restrictions on the press, thus ensuring greater freedom of expression throughout colonial India. (p. 13).

Tickell overlooks the fact that for people like Kylas, such ambivalence was inevitably conditioned by the very nature of their education and location. It is not lack of scruples, nor inconsistency, but ambivalence that characterizes Kylas' and also Shoshee Dutt's attitude. In Terrorism, Insurgency and Indian English Literature, Tickell also suggests that both Kylas and Shoshee later became revenue collectors and "amended their youthful radicalism accordingly". (Tickell, p. 6o) But he misses the fact that Shoshee in later years not only went on to write far more intriguing critiques of the empire but also countered the grand narrative of the British version of Indian history. ${ }^{\text {viii }}$

The failure of the mutineers at the end of the text may have to do with the fact that the mutineers belong to the educated middle and upper middle class elite, and they did not enlist the support of the masses. Kylas was prudent enough to realize the difference between the desire for freedom and its execution. Kylas (by means of his western education) had imbibed Western ideas of freedom, but, was also aware that those ideas could not be realized practically so easily. Thus, though the desire for "freedom" is intense, his psyche could not accommodate a successful rebellion for acquiring that "freedom". But it is significant that the vision of freedom had already taken root, and Indians had already begun to imagine freedom and contest existing constructions of identity as colonial subjects and acceptance of colonial rule.

Though the rebellion is "unsuccessful", the leader of the rebels, Bhoobun Mohun, standing in the face of death, continues to inspire his countrymen: 
My friends and countrymen! I have the consolation to die in my native land... I have shed my last blood in defence of my country and ... I hope, you will continue to persevere in the course we have so gloriously commenced. (p. 20)

Sisir Kumar Das has observed that,

The passionate speech of the leader of the rebels before his execution reminds one of the freedom fighters yet unborn. When one remembers the series of uprisings in India- Garo movement in Mymensingh, Nayeks insurrection, Paik insurrection, to mention a few and also the attitudes of the Muslims towards British rule-- the story appears as a formidable document of distrust and hatred against the British rule. It is ironical that this first expression of patriotism as well as hatred for the British rule in Indian literature was recorded in the English language. (p. 8o)

Bhoobun Mohan's speech might have been inspired by Robert Emmet's (1778-1803) “The Speech from the Dock”, which was widely quoted and remembered not only by Irish nationalists, but also by Indian nationalist periodicals during the nationalist movement for freedom. Of course there is no definitive proof that Emmet's speech was read by Kylas, but there is reason for us to conjecture so because under the guidance of his teacher Henry Louis Vivian Derozio, Kylas and all other students of the Hindu College were made to read revolutionary texts such as those by Tom Paine and Voltaire.

In Terrorism, Insurgency and Indian English Literature, Tickell writes that Kylas was too young to be taught by Derozio at the Hindu College (Tickell, p. 6o.) But it is erroneous to tag Kylas and Shoshee together since Kylas was born in 1817 and Shoshee in 1824. They did not go to college together. In 1831, Kylas was fourteen years old and Shoshee only seven. Derozio served in the Hindu/ Hindoo College from 1826-31. Kylas studied in the college from 1830-37. So it is extremely likely that Kylas did come under Derozio's influence.

Kylas Dutt's Forty-Eight Hours is not only remarkable for its bold attitude to colonialism, but also for its negotiation with the English language and English education. The autobiographical account of Rabindranath Tagore in Jiban Smriti (1912), for instance, speaks retrospectively of the 188 os and gives us a hint about the reception and assimilation of Western literature in Nineteenth Century India:

Our literary gods were Shakespeare, Milton and Byron. What moved us most in their work was the predominance of passion, something that remained concealed in British social behaviour, but surfaced with intensity in literature. Excess of emotion culminating in a passionate explosion: this seemed the characteristic feature of this literature. At least what we learnt to think of as the quintessence of English literature was this unbridled passion... the fury of King Lear's impotent lamentation, the all consuming fire of Othello's jealousy - these contained an excess that fuelled our imagination (Quoted in Meenakshi Mukherjee, The Perishable Empire pp. 6-7)

The inspirational ability of which Tagore speaks in the above passage helps us to understand Dutt's use of the following passage from Junius Brutus as an epigraph to his text: "And shall we, shall men, after five and twenty years of ignominious servitude, shall we, through a fear of dying defer one single instant to assert our liberty? No, Romans, now is the time; the favourable moment we have been waiting for is come. "ix Kylas' use of this passage from Junius Brutus marks multiple transcultural and translingual negotiations. Kylas re-contextualizes this passage from Duncombe, who was himself using the Roman situation as an inspiration for his own times. Four 
months after the publication of Forty-Eight Hours, Kylas made the following remark in an article titled "India under Foreigners", published in The Hindu Pioneer, a periodical edited by himself,

The violent means by which Foreign Supremacy has been established and the entire alienation of the people of the soil from any share in the government... are circumstances which... no commercial, no political benefits can ever authorize or justify (Italics mine).

Kylas here completely rejects the civilizing mission theory used by the colonisers to justify their imperial ambitions. He points out that the British are alienated from the people of the soil, and that they have denied the Indians any share in the government. And that is why any civilizing or moralizing mission is but a poor apology, a mere excuse to carry on with the colonial project.

Kylas was not the only one to realize the exploitative nature of the British Rule. Harish Mookherjee for instance writes that

"There is not a single native of India who does not feel the full weight of the grievances imposed upon him by the very existence of the British Rule in India- grievances inseparable from subjection to a foreign rule. There is not among the educated classes [one] who does not feel his prospects circumscribed and his ambition restricted by the supremacy of that power" (Quoted in Dilip Majumder, p. 114).

Tickell's comment that "Kylas' short story is an unusual literary hybrid, and could be dismissed as a hasty pastiche of some of the more radical poetic and philosophical additions to the Hindu College curriculum" ("Introduction" in Dutt, Bengaliana p. 13), shows poor perception of the text. Forty-Eight Hours is anything but a "pastiche". Rather, it is a document that records the earliest response of the Western educated Indian to the British Rule. Its value need not be diminished because it has at its centre "imported principles of liberty and constitutional freedom" (14). While it is a prevalent idea that "the institution of 'Literature' in the colony is under the direct control of the imperial ruling class, ... So, texts of this kind come into being within the constraints of a discourse and the institutional practice of a patronage system which limits and undercuts their assertion of a different perspective" (Ashcroft et al. 2002), the empire, it is time we realize, had started writing back much earlier than it is commonly believed.

As is observed by Meenakshi Mukherjee in The Perishable Empire,

"When Thomas Babington Macaulay spoke of 'the imperishable empire of our arts... and literature...' which would outlast the sceptre, he could not have anticipated the way history would rewrite the terms of that continuity." (p. xi)

History certainly asks us to re-consider/re-view the coloniser-colonised negotiations. While sufficient attention has been paid to the theory of complicity, it is today crucial that we also begin to look at the counter-texts of contestation. The colonial period was in no way a period of homogeneous/total textual dominance. The colonial subject, particularly he who had the advantage of Western education, was not an imperial agent as he is so conveniently theorised to be. There is no doubt a sense of ambivalence in his attitude to the imperial rule, but that did not in any way blind him from seeing the colonial rule in an analytical manner, with all its inherent defects, nor did it deter him from representing himself. His vision was certainly not as impaired as it is made out to be, because as early as 1835 , he could envision a rebellion against the colonial rule. Although at times characterised by ambivalent or hybrid situatedness, generated by the interplay of western education, imperial discourses and indigenous culture and tradition, this text certainly embodies a will to representation and rebellion. 


\section{Notes}

${ }^{\mathrm{i}}$ It is widely held by scholars and literary historians that the rise and growth of indigenous literatures in nineteenth century India largely owes itself to the introduction of the English education. Amit Chaudhuri echoes the same idea when he says: “... the rise of the Bengali language, the subsequent Bengal and Indian Renaissance, and the creation, in Bengali, of the first modern Indian literature were related directly to the fact Bengali became a respectable, and then the principle, medium of expression among the educated Bengali middle classes, who had, before, in the early days of education, preferred to write in English. The story of other vernaculars and their increasingly significant literatures is more or less similar." (p. xxi)

ii The socio-political and cultural impact of the colonial process from the moment of colonization to the present day is here designated as postcolonial. The term "post-colonial" when used in this hyphenated form places stress on the chronological meaning - that the "post" phase started after colonialism came to a formal political end. It is important to transcend the periodicity the term postcolonial evokes since the term postcolonial should refer not to a simple periodization but rather to a methodological revisionism. Thus the implied chronological separation between colonialism and its aftermath is not really valid. It is true that postcolonial as a concept enters critical discourse in its current meanings in the late 1970s and early 1980 s, but both the practice and the theory of postcolonial resistance go back much further. In fact the postcolonial condition is inaugurated with the onset rather than with the end of the colonial occupation. Figures like M. K. Gandhi, Rabindranath Tagore, Frantz Fanon, Albert Memmi, the Carribean "negritude" writers presaged some of the positions now labeled postcolonial.

iii Desh-bodh is an utterly untranslatable term, because while bodh in Bangla corresponds to the English consciousness/perception, the exact nuances of the term desh is difficult, almost impossible, to conveydesh is at the same time 'motherland'/ 'homeland', 'nation' and 'country'. Desh relates to the notion of psychological and emotional belonging.

${ }^{\text {iv }}$ Having located it in the catalogues of the National Library, I realized soon enough that the text was not to be found there nor in any of the archives in Bengal. After having repeatedly searched for four years I finally found the text on the internet on http://www.tandf.co.uk/journals (Wasafiri Vol. 21, No. 3 November 2006) 15- 20.

v Alex Tickell, “Midnight's Ancestors”, Wasafiri. Vol. 21, No. 3 November 2006. Kylas Dutt's lost text was "found" by Alex Tickell who re-printed it in the Journal Wasafiri (vol. 21, No. 3 November 2006) 15-20. All references to the text are from here.

${ }^{v i}$ Mohan means charming/fascinating, and it is a part of three of Krishna's hundred and eight names. According to Alex Tickell, 'One of Kylas's closest student friends, Bhuban Mohan Mittre may have provided a model for his protagonist' (Midnight's Ancestors). In Krishna Charitra, Bankim Chandra endeavours to discover Sri Krishna, the real person, behind centuries of myths and legends. Written in 1886, this was the first instance where the character of Krishna is studied from a pragmatic and questioning perspective. Like his novel Ananda Math, Krishna Charitra originates from Bankim Chandra's passionate feeling of patriotism. He wanted to uphold Sri Krishna as not just a mythological figure, but an ideal Indian character, whom other Indians could look up to.

vii Kylas' mention of The Calcutta Courier was not taken too kindly by the journal authorities. Calling Kylas a 'traitor', the following remarks were made in the paper: 'When the British Parliament ordered a sum to be set apart out of the revenues of India, for instructing a native population it never could have been intended to teach them sedition. (The Calcutta Courier, $10^{\text {th }}$ June, 1835)

viii Shoshee Dutt's Shunker: A Tale of the Indian Mutiny of 1857 (published in Bengaliana, 1892), interrogates British historiography of the "mutiny" of 1857, and The Young Zemindar: His Erratic Wanderings and Eventual Return: Being a Record of Life, Manners, and Events in Bengal of from Forty to Fifty Years ago (1885) takes the reader on a tour of India under the guidance of a mysterious sanyasi who inspires the people of India to unitedly fight the ferangis irrespective of their religion. Shoshee's Reminiscences of a Kerani's life 
(published in Bengaliana, 1892) displays strong self-determination and subverts the stereotypical notions about the kerani.

ix Junius Brutus (1735) is a verse drama by William Duncombe (1690-1769). The play makes frequent appeals to "liberty," in keeping with the 'Patriot' plays of disaffected Whigs.

\section{References}

Ashcroft, Bill. et al. (2002). The Empire Writes Back. London: Routledge.

Bose, Amalendu. (1967-68). Bengali Writing in English in the Nineteenth Century. Bulletin of the Department of English of Calcutta University (New Series). 3(2), 5.

Chatterjee, Partha. (1999). The Partha Chatterjee Omnibus. Delhi: Oxford University Press.

Chaudhuri, Amit. (Ed.). (2001). The Picador Book of Modern Indian Literature. London: Picador.

Chaudhuri, Rosinka. (2005). "The Dutt Family Album: And Toru Dutt", in An Illustrated History of Indian Literature in English, ed. Arvind Krishna Mehrotra. Orient Blackswan Private Limited: New Delhi

Das, Sisir Kumar. (1991). A History of Indian Literature 1800-1910 Western Impact: Indian Response. New Delhi: Sahitya Akademi.

Dutt Kalyan Chunder. (2017). The Pindari Lover and Other Writings of Kylas Chunder Dutt. Power Publishers: Kolkata

Dutt, Kylas Chunder. (November 2006) 'A Journal of Forty-Eight Hours of the Year 1945'. Wasafiri, 21(3), 1520.

Dutt, Shoshee Chunder. (2005). Selections from Bengaliana. Alex Tickell (Ed.). Nottingham: Trent Editions

Fanon, Frantz. (1967). Black Skin White Masks. New York: Grove. Reprint of Peau noire, masques blancs. Paris, 1952

Gandhi, Leela. (1998). Postcolonial Theory. New Delhi: Oxford University Press.

Gough, Kathleen. (1974). "Indian Peasant Uprisings“, in Economic and Political Weekly, 9(32-33-34), 13911412.

Gramsci, Antonio. (1971). (Eds.). Hoare Quintin and Geoffrey Nowell Smith. Selections From the Prison Notebooks of Antonio Gramsci. London: Lawrence and Wishart.

Guha, Ranajit. (1987). “Chandra’s Death” in Ranajit Guha (Ed.), Subaltern Studies V (pp. 135-65) Delhi: OUP.

- (1997). Dominance without Hegemony: History and Power in Colonial India. USA: Harvard University Press.

Haq, Kaiser. (2005). “Introducing South Asian Poetry in English: The Dutts of Rambagan”, The Daily Star. 5 (315).

Kopf, David. (1969). British Orientalism and the Bengal Renaissance: The Dynamics of Indian Modernization 1773-1835. Berkeley: University of California Press.

Mandal, Somdatta. (Ed.) (2014). A Journal of Forty-eight Hours of the Year 1945. Calcutta: Shambhabi.

Majumder, Dilip. (1983). Harish Mookherjee: Jiban o Bhabna (Harish Mookherjee: Life and Thought). Calcutta: Nabajatak.

Mukherjee, Meenakshi. (2000). The Perishable Empire. New Delhi: Oxford University Press.

Mund, Subhendu. "Kylas Chunder Dutt: The First Writer of Indian English Fiction”. 
- "The Republic of Orissa: A Page from the Annals of the Twentieth Century by S.C.Dutt." Sateertha Bulletin. Spring, 1995.

Nandy, Ashis. (1983). The Intimate Enemy: Loss and Recovery of Self under Colonialism. New Delhi: Oxford University Press.

Panikkar, K. N. (2005). Colonialism, Culture, and Resistance. New Delhi: Oxford University Press.-

Said, Edward. (1978). Western Conceptions of the Orient. London: Routledge and Kegan Paul.

Sanyal, Jharna. (2002). "Reading Ireland Writing India: The Postcolonial and Transnational Narratives in the Jugantar (1906-08)", in Narrating the (Trans)nation: The Dialectics of Culture and Identity. Krishna Sen and Sudeshna Chakravarti. (Eds.).

Sarma, Govind Prasad. (1978). Nationalism in Anglo-Indian Fiction. New Delhi: Sterling Publishers Pvt. Ltd.

Spivak, Gayatri Chakravorty. (1988). "Can the Subaltern Speak? Speculations on Widow Sacrifice", in Marxism and the Interpretation of Culture. Cary Nelson and Larry Grossberg. (Eds.). Chicago: University of Illinois Press.

Tagore, Rabindranath. (1996). The English Writings of Rabindranath Tagore. New Delhi: Sahitya Akademi.

Jacoby, W. G. (1994). Public attitudes toward government spending. American Journal of Political Science, 38(2), 336-361.

Tickell, Alex. (2006). "Midnight's Ancestors”, Wasafiri, 21(3), 10-14.

- (2012) Terrorism, Insurgency and Indian-English Literature, 1830-1947. London: Routledge.

Viswanathan, Gauri. (1990). Masks of Conquests: Literary Study and British Rule in India. London: Faber.

\section{Periodicals}

The Hindu Pioneer, October 1835.

Dr. Paromita Sengupta, Assistant Professor in English, teaches English Literature at the Undergraduate and Postgraduate levels. Her Doctoral Research was in the area of Nineteenth Century Indian Writing in English. Currently she is working on a Research Project funded by UGC, India which is titled “Travelling Nationalisms, Transitional Histories". Her areas of research include Postcolonial Studies, Gender Studies and Subaltern Studies. 